Sains Malaysiana 49(9)(2020): 2293-2300

http://dx.doi.org/10.17576/jsm-2020-4909-26

\title{
Density Measurement, Tensile, and Morphology Properties of Polylactic Acid Biocomposites Foam Reinforced with Different Kenaf Filler Loading
}

(Ukuran Ketumpatan, Sifat Regangan dan Morfologi Biokomposit Berbusa Asid Polilaktik Berpenguat Pengisi Kenaf dengan Pembebanan Berbeza)

\author{
Nur Adilah Abu Hassan, SAHrim Ahmad \& RUEy Shan Chen*
}

\section{ABSTRACT}

This paper investigates the performance of polylactic acid (PLA)/kenaf fiber (KF) composites foamed using azodicarbonamide $(A C)$ in terms of density, mechanical, and morphology aspects. The KF loading was varied in the range of 20-40 wt. \%. The mixtures were compounded using a co-rotating twin-screw extruder and followed by hotcold pressing in order to prepare test specimens for characterization. The density of the foamed composites showed a fluctuate trend where it decreased at lower KF loading (0-20 wt. \%) while further increasing fiber loading (30-40 wt. \%) resulted in an increase of the composites density. Tensile results showed that the optimum loading of KF was achieved at $30 \mathrm{wt} . \%$ with an improvement of 135, 153, and 27.6\% for stress at yield, strain at break and Young modulus, respectively, as compared to neat PLA foam. Field emission scanning electron microscope (FESEM) micrographs confirmed the fiber dispersion and morphological interaction between PLA and KF components.

Keywords: Biopolymer; foaming process; lightweight material; mechanical properties; microcellular foam

\section{ABSTRAK}

Kertas ini mengkaji prestasi komposit asid polilaktik (PLA)/gentian kenaf (KF) dibusakan dengan menggunakan azodikarbonamida $(A C)$ dari segi aspek mekanik, ketumpatan dan morfologi. Kandungan KF divariasikan dalam lingkungan 20-40\% bt. Campuran diadunkan dengan menggunakan mesin penyemperit skru berkembar searah dan diikuti dengan penekanan panas dan sejuk bagi menyediakan spesimen untuk dianalisis. Ketumpatan bagi komposit berbusa menunjukkan tren turun-naik kerana ia menurun pada kandungan KF yang rendah (0-20\% bt.) manakala kandungan KF yang semakin meningkat (30-40\% bt.) telah menyebabkan peningkatan ketumpatan komposit. Keputusan ujian regangan menunjukkan bahawa kandungan optimum KF telah dicapai pada $30 \%$ bt. dengan peningkatan sebanyak 135, 153 dan 27.6\% masing-masing pada kekuatan regangan, pemanjangan pada takat putus dan modulus Young berbanding dengan PLA berbusa. Mikrograf pancaran medan mikroskop elektron pengimbasan (FESEM) mengesahkan penyebaran gentian dan interaksi antara muka antara komponen PLA dan KF.

Kata kunci: Bahan ringan; biopolimer; busa mikrosel; proses membusa; sifat mekanik

\section{INTRODUCTION}

Advances in conventional plastics made from petroleum brought noteworthy benefits to human life. However, the widespread use of them became a considerable concern due to their negative impact on environment and dependency on depleting fossil fuels resources (Wang et al. 2011). The increase of community awareness in environmental, the latest environmental regulation is drawing attention from researchers and academicians to widen the utilization of biopolymer and natural fiber in polymer composites industry due to their sustainability and eco-green nature. Therefore, there is an urgent need to develop sustainable and eco-friendly commodity to replace the utilization of the conventional feedstock (petroleumbased plastics). Among the biopolymers, polylactic acid (PLA) was found as the most compromising biodegradable materials since it is readily susceptible to biological attack (Ibrahim et al. 2010).

Since PLA is one of eco-friendly thermoplastic polyester with unique features which is comparable to 
conventional plastics (Han et al. 2012), it became the highest demand of biopolymer to be used in application that are hard to be recycled. PLA had been universally used with a wide range of application (Sun et al. 2017) and commonly used to replace the commodity synthetic polymers that cause deterioration on our environment (solid waste pollution). It also provides mechanical, good optical, physical and barrier properties as compared to conventional polymer (Shahdan et al. 2018). However, the applications of PLA are still limited since it is brittle, stiff, and low molecular weight which affects the melt viscosity, melt strength, and thermal properties (Akhtar et al. 2016; Göttermann et al. 2016). Recent study argued that these melt properties could be the obstacle to produce low molecular weight polymer foam with uniform cell morphology. To overcome these drawbacks of PLA, many studies had been carried out and proved that the addition of natural fibers such as flax, hemp, jute, kenaf, and sisal as reinforcing filler is an effective method to improve PLA properties (Jandas et al. 2013). Recently, Kamarudin et al. (2018) reported the study of mechanical and morphological properties of the PLA - kenaf fiber composites with addition of vegetable oil-based plasticizer. Despite of the published works on PLA-kenaf fiber composites, the report on the factor of different kenaf fiber loading in affecting the foaming structure as well as its relationship with density, tensile, and morphology properties are still limited for PLA-kenaf fiber composites. Meanwhile, natural fiber is one of the environmentally friendly materials which possess good mechanical and physical properties as good as synthetic fiber (Muhammed et al. 2015). In recent years, natural fibers have been used as reinforcing material because of various advantages such as effortlessness of processing and high availability from renewable resources (Takagi et al. 2014). There are numerous recent published works presented on the utilization of natural fibers in biocomposites materials. For instance, Zhang et al. (2017) had blended the wood fiber with PLA to enhance the mechanical properties of PLA matrix. According to Khoo and Chow (2017), the addition of sugarcane bagasse and epoxidized soybean oil as filler and plasticizer, respectively, had proven in improving the mechanical and thermal stability of PLA. However, excessive fiber content could lead to agglomeration due to poor interfacial interaction between polymer matrix and fiber, resulting in lower mechanical strength (Wang et al. 2011).

Nevertheless, the addition of natural fibers has been recognized to increase the density of bio-composites produced thus increasing the final weight of the end products as well as the transportation cost and fuel consumption. This concern led to exploration of new method for reducing the weight of the products while maintaining the performance and sustainability of the biocomposites. Recent findings found that foaming method could produce lightweight materials and have been chosen to substitute traditional production of materials in various industries (Najafi et al. 2015). Previous works done by Pilla et al. (2009) showed that the microcellular foaming decreased the specific toughness at $75 \%$ from neat PLA foam to 1 wt. \% flax fiber of PLA composites. In spite of many reports regarding on bio-composites foam, it is worth noting that this study appeared to be rarely documented on the focus of the effect of kenaf loading on density, mechanical, and morphology properties of PLA composites foam.

\section{MATERIALS AND METHODS}

MATERIALS

Commercial PLA 3251D Natureworks Ingeo $^{\text {TM }}$ with a density of $1.24 \mathrm{~g} / \mathrm{cm}^{3}$ and melt flow index (MFI) 30-40 g/10 min for $190^{\circ} \mathrm{C} / 2.16 \mathrm{~kg}$ was supplied by Unic Technology Ltd, China. The melting temperature range of PLA is between 188 and $210^{\circ} \mathrm{C}$. Kenaf fiber (KF) powder with a particle size of 100-150 $\mu \mathrm{m}$ was supplied by Kenaf and Tobacco State (LKTN). Chemical foaming agent, namely azodicarbonamide (AC), with a decomposition temperature between $170-200{ }^{\circ} \mathrm{C}$ and zinc oxide $(\mathrm{ZnO})$, a foaming agent decomposition stabilizer were supplied by Sigma Aldrich.

\section{SAMPLE PREPARATION}

Before processing, PLA and $\mathrm{KF}$ were oven dried at $80^{\circ} \mathrm{C}$ for $24 \mathrm{~h}$ in order to remove the moisture content. The specimens of foamed PLA/KF bio-composites were prepared by using co-rotating twin screw extruder machine (Thermo Prism THE 16PC) with a constant rotation speed of $40 \mathrm{rpm}$ and extrusion temperature profiles of $165,170,175,165^{\circ} \mathrm{C}$. The loadings of $\mathrm{AC}$ and $\mathrm{ZnO}$ were fixed at 3.0 and 1.5 phr. The mixture ratios of PLA:KF bio-composites were varied at 80:20, 70:30, 60:40 (wt:wt)\%. The formulation for each composition is tabulated in Table 1 . The mixtures of PLA/KF/AC/ZnO were tumble-mixed in a sealed plastic bag before extrusion. The mixing process was started by inserting the mixtures simultaneously into the feed port of the extruder. After extrusion process, the extrudates were cooled in a room temperature then ground into small pellets by using a crusher. The fine granules were put into the mold and then compression molded by hot and cold process (LP50, LABTECH Engineering Company) in order to make the specimen panels for testing. The compression molding was performed at $180^{\circ} \mathrm{C}$ under a pressure of 1000 psi $13 \mathrm{~min}$ ( $3 \mathrm{~min}$ for preheating, $2 \mathrm{~min}$ for venting, $5 \mathrm{~min}$ for full pressing, and $3 \mathrm{~min}$ for cold pressing. 


\section{DETERMINATION OF DENSITY}

The density $(\rho)$ of neat PLA foam and PLA composites foam was determined by using the following equation (1):

$$
\rho=\frac{m}{v}
$$

where $m$ is mass of the neat PLA foam and PLA composites foam while $v$ is the volume of the neat PLA foam and PLA composites foam. The mass and volume were measured by using a laboratory digital balance and vernier caliper, respectively. The average density of the specimens was measured by at least five specimens for each composition of neat PLA foam and PLA/KF composites foam.

\section{MECHANICAL TESTING}

Tensile properties of the specimens were determined by following ASTM D638-03 (type I). Tensile test was carried out by using a universal testing machine (Testometric M350-10CT) with a load cell and crosshead speed of 5 $\mathrm{kN}$ and $55 \mathrm{~mm} / \mathrm{min}$, respectively. The reported results of tensile test are the average values attained from at least ten specimens from each composition.

\section{FIELD EMISSION SCANNING ELECTRON MICROSCOPY (FESEM)}

FESEM (model LEO 1450 VP) was operated at accelerating voltage of $14 \mathrm{kV}$. Specimens were sputter coated by a thin layer of iridium to reduce electrostatic charging prior the imaging.

The void fraction (Vf) and expansion ratio (ER) were calculated by using equations (2) and (3):

$$
\begin{gathered}
\text { Void fraction }(V f)=\frac{\rho_{u}-\rho_{f}}{\rho_{u}} \\
\text { Expansion ratio }(E R)=\frac{\rho_{u}}{\rho_{f}}
\end{gathered}
$$

where $\rho_{u}$ is density of unfoamed; and $\rho_{f}$ is density of foam PLA/KF composites foam.

\section{RESULTS AND DISCUSSION}

\section{DENSITY}

Figure 1 represents the density measurement against the fiber loadings of PLA/KF composites foam. The foam density of neat PLA (0 wt. \% of KF) was at $1.09 \mathrm{~g} / \mathrm{cm}^{3}$. The density of composites foam increased accordingly with fiber loading which was appeared as $1.20 \mathrm{~g} / \mathrm{cm}^{3}$ for 20 wt. $\%, 1.25 \mathrm{~g} / \mathrm{cm}^{3}$ for 30 wt. $\%$ and $1.24 \mathrm{~g} / \mathrm{cm}^{3}$ for 40 wt. $\%$. The percentage difference of density from the neat PLA foam for each fiber loading is 2.86, 0.65 and $0.14 \%$, respectively. This trend is closely similar to the previous study done by Teymoorzadeh and Rodrigue (2016). The increment of density values is due to the fact that the presence of KF contributed to an increase in mass of PLA/ KF composites foam (Karim et al. 2016). This is expected in which the presence of KF may disturb the crystallinity in PLA matrix and the amount of gas absorbed in the composites in which the dissolved gas is dependent on the fiber loading in composites system (Bergeret \& Benezet 2011; Matuana \& Faruk 2010). As the fiber loadings increase, the interaction between fiber-matrix is also affected due to insufficient polymer matrix to wet out the fiber thus leads to the fluctuate density trend of PLA/KF composites foam (Chen et al. 2016; Ibrahim et al. 2010).

Figure 2 shows the effect of fiber loadings on the void fraction (Vf) and expansion ratio (ER) of the PLA/KF composites foam. As the fiber loadings increase, both Vf and ER show fluctuate trend where it drastically decreases from $20 \mathrm{wt}$ \% (3.78 of Vf and 1.04 of ER) to $30 \mathrm{wt}$ \% ( 0.31 of $\mathrm{Vf}$ and 1.00 of ER) and starts to increase as the fiber loading increases up to 40 wt. \% (0.82 of Vf and 1.00 of ER). This fluctuate trend is manipulated by the density of the PLA/KF composites and tally with the FESEM micrograph. The anticipation of the VF and ER trends can be attributed by the concentration of dissolved gas in the polymer matrix and the number of foam cells (Matuana \& Faruk 2010; Matuana et al. 2009).

\section{TENSILE PROPERTIES}

The stress at yield, strain at break and Young modulus of $\mathrm{PLA} / \mathrm{KF}$ composites foams with different loadings of KF are shown in Figure 3. As shown in Figure 3(a), the tensile properties increase with the increasing of KF loading up to $30 \mathrm{wt} . \%$. It is observed that a vastness processing is available for PLA foam formation by using natural fiber as reinforcement (Bocz et al. 2016). However, the tensile strength of the PLA/KF composites foams then drops at 40 wt. $\%$ of fiber loading because the existing matrix content might not be sufficient in wetting the fiber. This is supported by Ibrahim et al. (2010) who reported insufficient wetting of fibers by $30 \mathrm{wt}$. \% polymer. As stated by Chen et al. (2014) and Neagu et al. (2009), the addition of fiber loading has highly affected the microstructure of the foamed cells. The decrement in tensile strength of the composites foam may due to the poor interfacial adhesion between PLA matrix and KF as shown in FESEM micrograph (Figure 4) with the presence of fiber agglomeration in PLA matrix especially in the case of higher KF loading that probably weaken the bonding between polymer matrix and fillers. 
Theoretically, the maximum fiber volume should be found at around $80 \mathrm{wt}$. \%, however, the experimental and theoretical results can be differed due to viscosity of matrix polymer and characterization of fibers. As proven in this research, the mechanical properties were improved with the optimum fiber volume (30 wt. \%) but decreased as more fiber volume incorporated, in which the findings are supported by Chen et al. (2015) and Hafizah et al. (2014). Figure 3 shows the percentage differences of the tensile properties for 20,30 , and $40 \mathrm{wt}$. \% KF as compared to that of neat PLA foam. The tensile strength peaks, strain at break and Young Modulus increase about 9 - 134\%, 15 - $154 \%$, and 7 - 28\%, respectively.

In short, $30 \mathrm{wt} . \%$ is found to be optimum fiber loadings which shows the highest increment by $135 \%$ for tensile strength, $153 \%$ for strain at break and $27.6 \%$ for Young modulus as compared to the neat PLA foam. Though, for the fiber loading higher than 30 wt. \%, the tensile properties start to reduce by about 30,25 , and $17 \%$ for tensile strength, strain at break and Young Modulus, respectively. The reduction in Young Modulus is the lowest as compared to tensile strength and strain at break because it is established to be less sensitive to interfacial interaction (Chen et al. 2015). However, the Young Modulus for $40 \mathrm{wt}$ \% KF composites has obtained similar level with that of neat PLA matrix as shown in Figure 3(c). The overall mechanical property reduction is due to effect of the affected viscosity of polymer matrix and agglomeration of fibers in PLA matrix as there are no polymer chains between fibers layers as observed in the study of Ibrahim et al. (2010). As proven and supported in FESEM micrograph, when the fiber loading exceeds 30 wt. \%, some voids and weakened fiber contacts are seen which is caused by insufficient amount of polymer matrix. Therefore, the optimum fiber loading used for producing PLA reinforced composites foam is believed to be kept at 30 wt. $\%$.

\section{CELLULAR MORPHOLOGY ANALYSIS}

The morphological structure, distribution, and cells size of foamed composites with different loadings of KF (0-40 wt. \%) are demonstrated in Figure 4. As shown in Figure 4(a), neat PLA shows a solid morphological structure without the presence of any cells. It can be observed that in Figure 4(b) - 4(d), the PLA/KF composites foam displays the foamable structure as the loading of KF increases up to $30 \mathrm{wt}$. \%. However, further increment of fiber loading (40 wt. \%) shows the irregular structure morphology and increased number of foamed cells. By comparing Figure 4(b), 4(c) and 4(d), the size of the foamed cells increases as the filler loading increases as compared to Figure 4(a). Similar observation has been reported in Karim et al. (2016) that the size of pores increases with the filler loading. The increase in size of foamed cells contributes to the reduction of tensile strength properties of the composites foam, as proven in Figure 3. Nevertheless, as the fiber loading is up to $40 \mathrm{wt}$. \%, the FESEM micrograph in Figure 4(c) shows the distribution with poor interaction between fiber-matrix proved by micro-spaces with rather limp or collapsed cell wall are characteristic for the highest fiber loading of PLA/KF composites foam.

For 20 and 30 wt. \% of fiber loading (Figure 4(b) and $4(\mathrm{c}))$, the fiber dispersion is found to be improved where the morphological structure and cells distribution seem homogenous, which has resulted in the better mechanical strength as compared to higher fiber loading composites foam (shown in Figure 3). This finding is in agreement with the study of Ibrahim et al. (2010) who proved that that 20 and 30 wt. \% of filler loading improved the fiber distribution and dispersion which in turn in greater mechanical properties of PLA/kenaf bast fiber composites in comparison to $10 \mathrm{wt}$ \% filler loading. At the same time, the higher fiber loading (40 wt. \%) reinforced composites foam exhibit a less-uniform foamed cells size which related to the distribution of polymer matrix-fiber and matrix-fiber interaction as displayed in Figure 4(d). Besides, there is another striking observation shown in Figure 4(d) that is local matrix-fiber de-bonding of foamed cells induced with non-uniform distribution of foamed cells size. The cell growing ability is greatly affected from the polymer matrix viscosity. For instance, the viscosity of the matrix must be concerned especially for producing foamable composites since the foamed cell growth is affected by a number of factors such as polymer rheological properties, gas diffusion coefficient, gas concentration, the geometry, and amount of filler particles and number of adjoining cells (Ding 2016). In general, as the fiber loading increases, the viscosity of the polymer of the melt reduces, thus promoting the heterogeneous cell nucleation and deteriorating the cell morphology of the PLA/KF composites foam.

As shown in Figure 4, the heterogenous cells sizes in 40 wt. $\%$ of fiber loading can be seen by large error bar in Figure 5. There is significant interaction between fiber loading and the sizes of cells foamed in PLA/ KF composites. Thus, the average cell sizes of foamed composites with different KF loadings are measured and are illustrated in Figure 5. Generally, the higher fiber loading shows significant decrease in cell sizes. This trend is expected since cell sizes are strongly dependent on fiber content as related to an increase in number of nucleating sites which induced by the fiber surface (Bergeret \& Benezet 2011). The error bars in the graph represent the standard deviation for the cell sizes where the greatest error bar is shown in $40 \mathrm{wt}$. \% as compared to 20 and 30 wt. $\%$ of KF. This result suggests the heterogenous cell nucleation in higher fiber loading and is tally with the morphology observations displayed in Figure 4. 
TABLE 1. Formulation of PLA/KF composites foam

\begin{tabular}{cccc}
\hline $\begin{array}{c}\text { PLA loadings } \\
(\text { wt. } \%)\end{array}$ & $\begin{array}{c}\text { KF loadings } \\
(\text { wt. } \%)\end{array}$ & $\begin{array}{c}\text { ADC loadings } \\
(\mathrm{phr})\end{array}$ & $\begin{array}{c}\text { ZnO loadings } \\
(\mathrm{phr})\end{array}$ \\
\hline 100 & 0 & 3 & 1.5 \\
80 & 20 & & \\
70 & 30 & \\
60 & 40 & \\
& \\
&
\end{tabular}

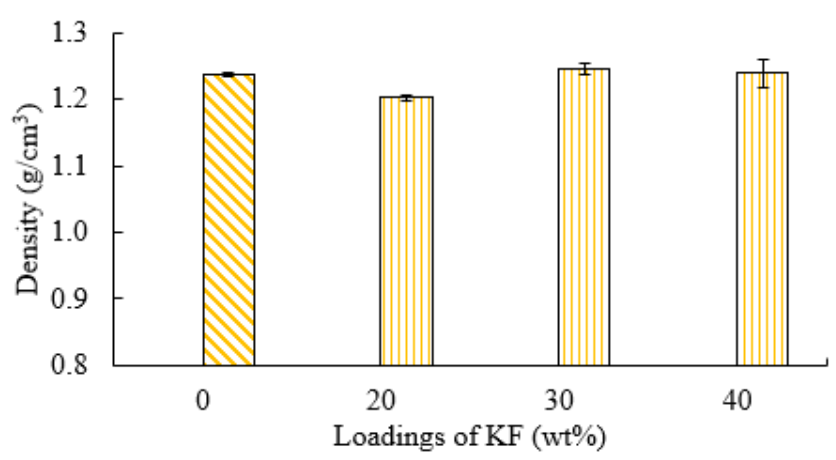

FIGURE 1. The effect of fiber loading on density of the PLA/KF composites foam

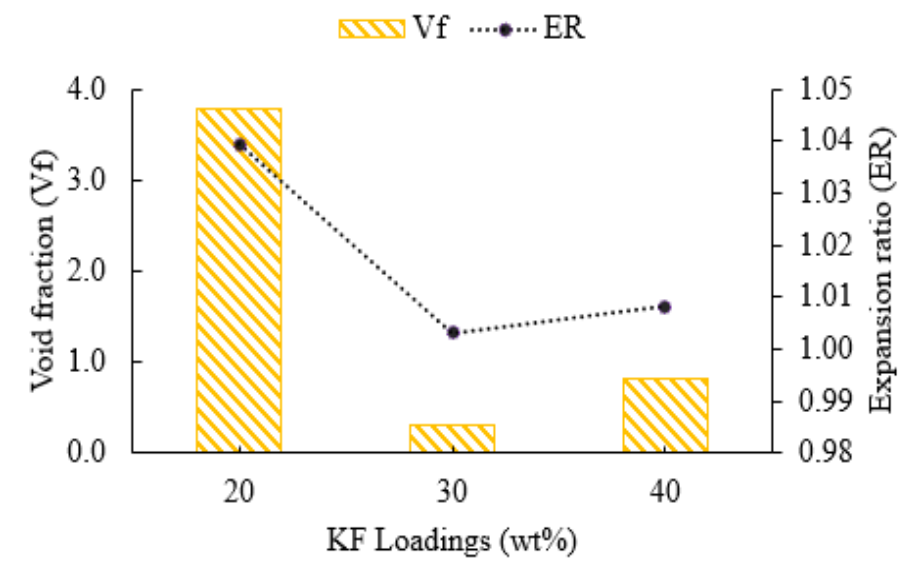

FIGURE 2. The effect of fiber loadings on the void fraction (Vf) and expansion ratio (ER) of PLA/KF composites foam

(a)

$\square$ PLA foam $\quad \square$ PLA/KF foam

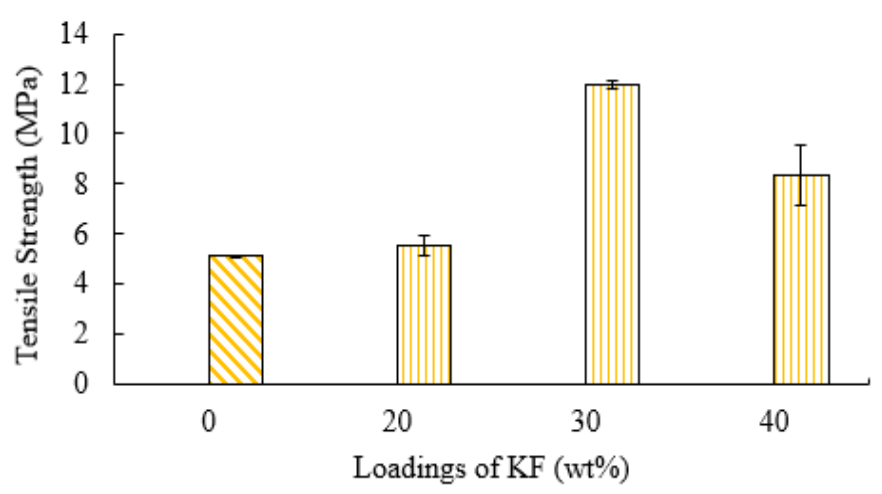



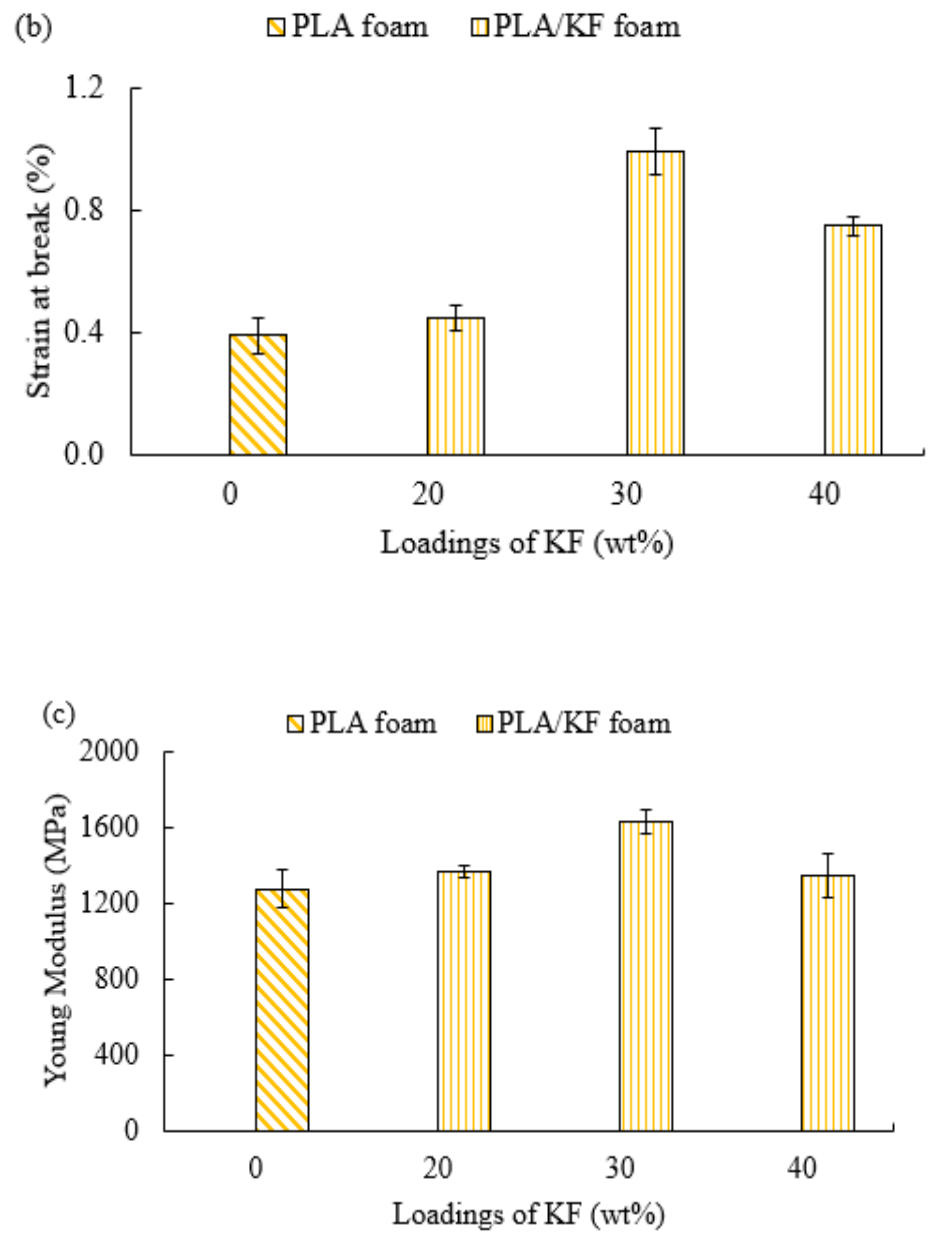

FIGURE 3. The effect of fiber loadings on tensile properties of PLA/ KF composites foam: (a) Tensile strength, (b) Strain at break, and (c) Young Modulus
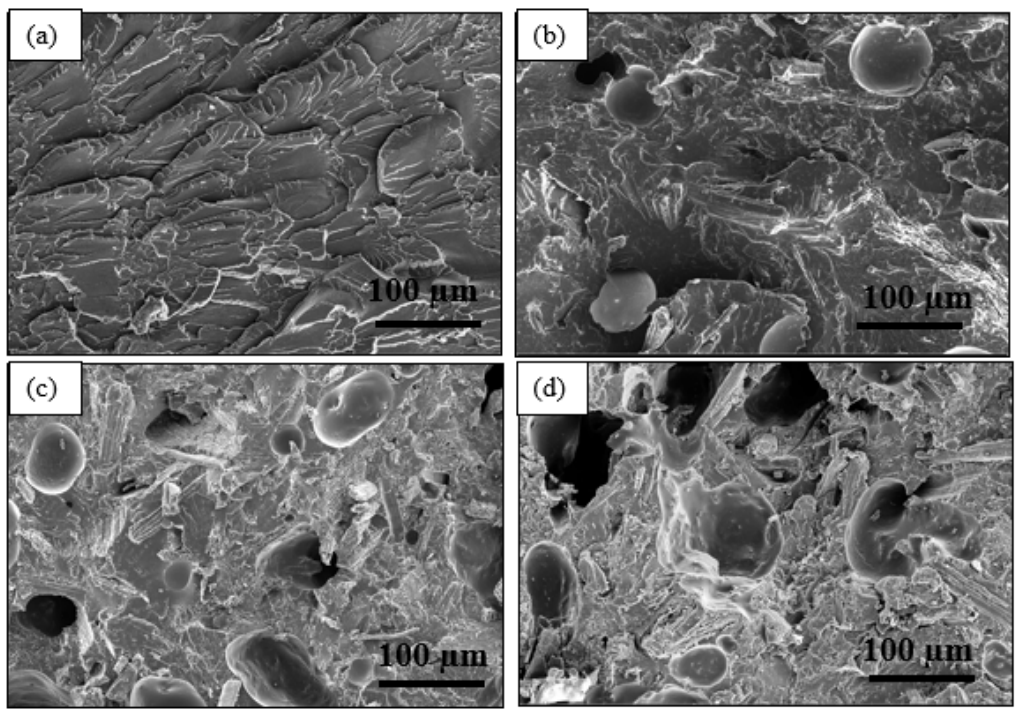

FIGURE 4. FESEM micrograph of the PLA/KF composites foam with (a) raw PLA, (b) 20 wt. \%, (c) 30 wt. \%, and (d) 40 wt. \% fiber 


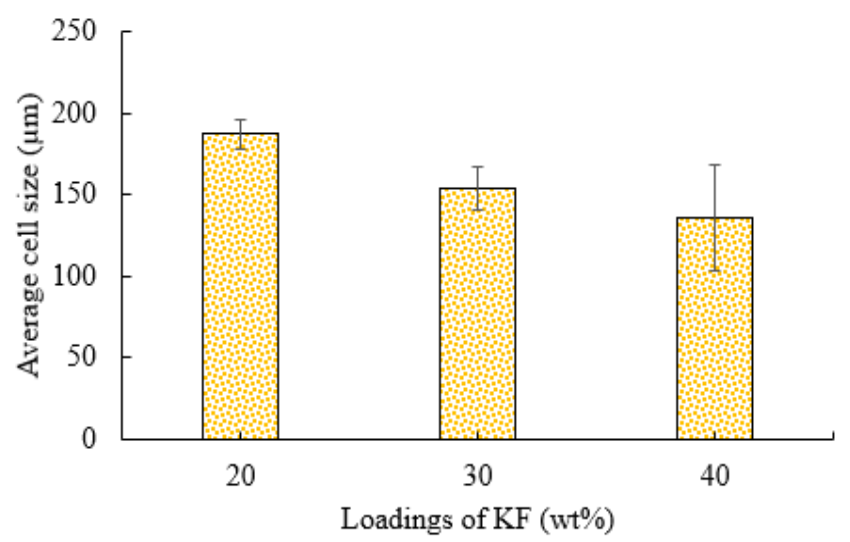

FIGURE 5. The effect of fiber loadings on average cell size of PLA/KF composites foam

\section{CONCLUSION}

PLA/KF composites foam with different fiber loadings was successfully prepared through extrusion and compression molding. The dependence of density, tensile and morphological properties on filler loadings was evaluated. The density showed a decrement in $20 \mathrm{wt}$. $\% \mathrm{KF}$ loading, but insignificant changes were shown in 30 and 40 wt. \% KF loading. As the fiber loading increased (0-30 wt. \%), the tensile properties of PLA/ KF composites foam increased, but further increasing the fiber loading (40 wt. \%) had resulted in decreasing trend. It can be concluded that the optimum fiber loading of $\mathrm{KF}$ was achieved at $30 \mathrm{wt} . \%$ with an improvement of 135 , 153 , and $27.6 \%$, respectively, for stress at yield, strain at break and Young modulus as compared to neat PLA foam. The morphology of the PLA/KF composites foam demonstrated the homogeneity of the foamed cells size and increase in the amount of cells generated with respect to the fiber loading.

\section{ACKNOWLEDGEMENTS}

The authors gratefully acknowledge the financial supports of the fund (grant number DIP 2018-031 and FRGS/1/2019/TK05/UKM/02/3) and Centre for Research and Instrumentation Management (CRIM) Universiti Kebangsaan Malaysia (UKM) during samples analyzation.

\section{REFERENCES}

Akhtar, M.N., Sulong, A.B., Radzi, M.K.F., Ismail, N.F., Raza, M.R., Muhamad, N. \& Khan, M. A. 2016. Influence of alkaline treatment and fiber loading on the physical and mechanical properties of kenaf/polypropylene composites for variety of applications. Progress in Natural Science: Materials International 26(6): 657-664. doi:10.1016/j. pnsc.2016.12.004.
Bergeret, A. \& Benezet, J.C. 2011. Natural fibre-reinforced biofoams. International Journal of Polymer Science 2011. doi:10.1155/2011/569871.

Bocz, K., Tábi, T., Vadas, D., Sauceau, M., Fages, J. \& Marosi, G. 2016. Characterisation of natural fibre reinforced PLA foams prepared by supercritical $\mathrm{CO}_{2}$ assisted extrusion. Express Polymer Letters 10(9): 771-779. doi:10.3144/ expresspolymlett.2016.71.

Chen, R.S., Ahmad, S., Gan, S., Salleh, M.N., Ab Ghani, M.H. \& Tarawneh, M.A. 2016. Effect of polymer blend matrix compatibility and fibre reinforcement content on thermal stability and flammability of ecocomposites made from waste materials. Thermochimica Acta 640: 52-61. doi:10.1016/j.tca.2016.08.005.

Chen, R.S., Ab Ghani, M.H., Ahmad, S., Salleh, M.N. \& Tarawneh, M.A. 2015. Rice husk flour biocomposites based on recycled high-density polyethylene/ polyethylene terephthalate blend: Effect of high filler loading on physical, mechanical and thermal properties. Journal of Composite Materials 49(10): 1241-1253. doi:10.1177/0021998314533361.

Chen, R.S., Ahmad, S., Ghani, M.H.A. \& Salleh, M.N. 2014 Optimization of high filler loading on tensile properties of recycled HDPE/PET blends filled with rice husk. AIP Conference Proceedings 51: 46-51. doi:10.1063/1.4895168.

Ding, W. 2016. Development of polylactic acid/cellulose nanofiber biocomposite foams development of polylactic acid/cellulose nanofiber biocomposite foams. University of Toronto. Ph.D. Thesis (Unpublished).

Göttermann, S., Weinmann, S., Bonten, C., Standau, T. \& Altstädt, V. 2016. Modified standard polylactic acid (PLA) for extrusion foaming. AIP Conference Proceedings 1779(1): 060001. doi:10.1063/1.4965522.

Hafizah, N.A.K., Hussin, M.W., Jamaludin, M.Y., Bhutta, M.A.R., Ismail, M. \& Azman, M. 2014. Tensile behaviour of kenaf fiber reinforced polymer composites. Jurnal Teknologi 69(3): 11-15. doi:10.11113/jt.v69.3138. 
Han, S.O., Karevan, M., Sim, I.N., Bhuiyan, M.A., Jang, Y.H., Ghaffar, J. \& Kalaitzidou, K. 2012. Understanding the reinforcing mechanisms in kenaf fiber/pla and kenaf fiber/pp composites: A comparative study. International Journal of Polymer Science 2012: Paper ID. 679252. doi:10.1155/2012/679252.

Ibrahim, N.A., Yunus, W.M.Z.W., Othman, M., Abdan, K. \& Hadithon, K.A. 2010. Poly(Lactic Acid) (PLA)-reinforced kenaf bast fiber composites: The effect of triacetin. Journal of Reinforced Plastics and Composites 29(7): 1099-1111. doi: $10.1177 / 0731684409344651$.

Jandas, P.J., Mohanty, S. \& Nayak, S.K. 2013. Surface treated banana fiber reinforced poly (lactic acid) nanocomposites for disposable applications. Journal of Cleaner Production 52: 392-401. doi:10.1016/j.jclepro.2013.03.033.

Kamarudin, S.H., Abdullah, L.C., Aung, M.M. \& Ratnam, C.T. 2018. A study of mechanical and morphological properties of PLA based biocomposites prepared with EJO vegetable oil based plasticiser and kenaf fibres. Materials Research Express 5(8): p.085314. doi: 10.1088/2053-1591/aabb89.

Karim, A.F.A., Ismail, H. \& Ariff, Z.M. 2016. Properties and characterization of kenaf-filled natural rubber latex foam. BioResources 11(1): 1080-1091. doi:10.15376/ biores.11.1.1080-1091.

Khoo, R.Z. \& Chow, W.S. 2017. Mechanical and thermal properties of poly(lactic acid)/sugarcane bagasse fiber green composites. Journal of Thermoplastic Composite Materials 30(8): 1091-1102. doi:10.1177/0892705715616857.

Matuana, L.M. \& Faruk, O. 2010. Effect of gas saturation conditions on the expansion ratio of microcellular poly (lactic acid)/wood-flour composites. Express Polymer Letters 4(10): 621-631. doi:10.3144/expresspolymlett.2010.77.

Matuana, L.M., Faruk, O. \& Diaz, C.A. 2009. Cell morphology of extrusion foamed poly(lactic acid) using endothermic chemical foaming agent. Bioresource Technology 100(23): 5947-5954. doi:10.1016/j.biortech.2009.06.063.

Mohammed, L., Ansari, M.N.M., Pua, G., Jawaid, M. \& Islam, M.S. 2015. A review on natural fiber reinforced polymer composite and its applications. International Journal of Polymer Science 2015: Paper ID. 243947. doi: $10.1155 / 2015 / 243947$.

Najafi, N., Heuzey, M.C., Carreau, P.J., Therriault, D. \& Park, C.B. 2015. Mechanical and morphological properties of injection molded linear and branched-polylactide (PLA) nanocomposite foams. European Polymer Journal 73: 455465. doi:10.1016/j.eurpolymj.2015.11.003.

Neagu, R.C., Cuénoud, M., Berthold, F., Bourban, P.E., Gamstedt, E.K., Lindström, M. \& Månson, J.A.E. 2009. Processing and mechanical properties of novel wood fibre composites foams. In International Conferences on Composite Materials (ICCM). https://www.researchgate. net/publication/268257395_Processing_and_mechanical_ properties_of_novel_wood_fibre_composites_foams.
Pilla, S., Kramschuster, A., Lee, J., Auer, G.K., Gong, S. \& Turng, L.S. 2009. Microcellular and solid polylactide-flax fiber composites. Composite Interfaces 16(7-9): 869-890. doi:10.1163/092764409X12477467990283.

Shahdan, D., Chen, R.S., Ahmad, S., Zailan, F.D. \& Mat Ali, A. 2018. Assessment of mechanical performance, thermal stability and water resistance of novel conductive poly(lactic acid)/modified natural rubber blends with low loading of polyaniline. Polymer International 6(8): 1070-1080. doi:10.1002/pi.5613.

Sun, Z., Zhang, L., Liang, D., Xiao, W. \& Lin, J. 2017. Mechanical and thermal properties of PLA biocomposites reinforced by coir fibers. International Journal of Polymer Science 2017: 1-8. doi:10.1155/2017/2178329.

Takagi, H., Nakagaito, A.N. \& Liu, K. 2014. Heat transfer analyses of natural fibre composites. High Performance and Optimum Design of Structures and Materials 137: 237-243. doi:10.2495/HPSM140211.

Teymoorzadeh, H. \& Rodrigue, D. 2016. Morphological, mechanical, and thermal properties of injection molded polylactic acid foams/composites based on wood flour. Journal of Cellular Plastics 54(2): 179-197. doi:10.1177/0021955X16671304.

Wang, Y., Qi, R., Xiong, C. \& Huang, M. 2011. Effects of coupling agent and interfacial modifiers on mechanical properties of poly (lactic acid) and wood flour biocomposites. Iran Polymer Journal 20(4): 281-294.

Zhang, L., Lv, S., Sun, C., Wan, L., Tan, H. \& Zhang, Y. 2017. Effect of MAH-g-PLA on the properties of wood fiber/ polylactic acid composites. Polymers 9(11): 5-8. doi:10.3390/ polym 9110591.

Nur Adilah Abu Hassan, Sahrim Ahmad \& Ruey Shan Chen* Department of Applied Physics

Faculty of Science and Technology

Universiti Kebangsaan Malaysia

43600 UKM Bangi, Selangor Darul Ehsan

Malaysia

Sahrim Ahmad \& Ruey Shan Chen*

Materials Science Programme

Faculty of Science and Technology

Universiti Kebangsaan Malaysia

43600 UKM Bangi, Selangor Darul Ehsan

Malaysia

*Corresponding author; email: chen@ukm.edu.my

Received: 15 October 2019

Accepted: 8 May 2020 